\title{
Um Corpo Marcado, Lugar Secreto das Palavras ${ }^{1}$
}

1 Um primeiro esboço deste trabalho foi apresentado no $\checkmark$ Congresso Internacional de Psicopatologia Fundamental e XI Congresso Brasileiro de Psicopatologia Fundamental, em Fortaleza, CE, em setembro de 2012. Não publicado nos anais do congresso.
A Marked Body, Secret Place of Words

Un Cuerpo Marcado, Lugar Secreto de las Palabras

Esperidião Barbosa Neto Universidade Federal de Alagoas Zeferino Rocha Universidade Católica de Pernambuco

http://dx.doi.org/10.1590/1982-3703002252013

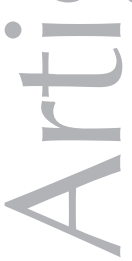


Resumo: O filme $A$ vida secreta das palavras realça o caráter traumático do sofrimento e a função da fala. Nele, o corpo se apresenta como palco dos efeitos da experiência dolorosa. A experiência subjetiva do trauma, inapreensível e difícil de ser suportada, volta sempre ao mesmo lugar, mas escapa; encontrá-la é impossível, por isso o sujeito repete a tentativa, insistentemente. Nessa perspectiva, pensamos a clínica psicanalítica como lugar de ressignificação da experiência afetiva traumática e a fala metafórica como recurso terapêutico de simbolização. O objetivo deste artigo é apresentar o filme $A$ vida secreta das palavras, articulando-o à repetição, no contexto da clínica psicanalítica, e à fala como recurso terapêutico, considerando as incidências do trauma no corpo. Tendo como referência o conceito psicanalítico de repetição, utilizaremos a teoria de Freud e de Lacan para fazer nossas reflexões. A partir do filme, apresentaremos o conceito de repetição, elaborado por Freud e por Lacan; situaremos a clínica psicanalítica como lugar da palavra, destacando a sua função metafórica, com o relato de uma observação clínica. Concluímos que a própria repetição porta a diferença, cabe ao analista intervir sobre ela, fazendo surgir a palavra, o que vai além do esvaziamento da tensão.

Palavras-chave: Trauma psíquico. Compulsão à repetição. Fala. Metáfora.

Abstract: The movie The Secret Life of Words emphasizes the traumatic nature of suffering and the function of speech. In the movie, the body appears as a stage for the effects of painful experience. The subjective experience of trauma, inapprehensible and difficult to be supported, always returns to the same place, but it escapes; it is impossible to find it, so the subject repeats the attempt, insistently. From this perspective, we think of the psychoanalytic clinic as a place of resignification for the traumatic affective experience, and of the metaphorical speech as a therapeutic resource for symbolization. The objective of this paper is to present the movie The Secret Life of Words, linking it to repetition in the context of clinical psychoanalysis, and to speech as a therapeutic resource, considering the implications of trauma on the body. Taking the psychoanalytical concept of repetition as a reference, we use the theory of Freud and Lacan to make our reflections. From the film, we present the concept of repetition, written by Freud and Lacan, and situate the psychoanalytic clinic as a place of the word, highlighting its metaphorical functions with a report of clinical observations. We conclude that repetition on its own harbors the difference, it is for the psychoanalyst to intervene on this, making the word appear, which goes beyond of the deflation of tension.

Keywords: Psychic trauma. Repetition compulsion. Speech. Metaphor.

Resumen: La película La vida secreta de las palabras destaca la naturaleza traumática del sufrimiento y la función del habla. En ella, el cuerpo aparece como escenario de los efectos de la experiencia dolorosa. La experiencia subjetiva del trauma, escurridizo y difícil de soportar, siempre vuelve al mismo lugar, pero se escapa; encontrarla es imposible, por lo que el sujeto repite el intento, con insistencia. En esta perspectiva, pensamos la clínica psicoanalítica como un lugar de reformulación de la experiencia afectiva traumática, y el habla metafórica como un recurso terapéutico para la simbolización. El objetivo de este trabajo es presentar la película La vida secreta de las palabras, haciendo una articulación a la repetición, en el contexto de la práctica psicoanalítica, y al habla como un recurso terapéutico, teniendo en cuenta el impacto del trauma en el cuerpo. Teniendo como referencia el concepto psicoanalítico de la repetición, utilizaremos la teoría de Freud y de Lacan para hacer nuestras reflexiones. De la película presentaremos el concepto de la repetición, elaborado por Freud y Lacan, situaremos la clínica psicoanalítica como lugar de la palabra, destacando su función metafórica, con el relato de una observación clínica. Concluimos que la propia repetición trae la diferencia, incumbe al analista de intervenir sobre esta, haciendo surgir la palabra, lo que va más allá del vaciamiento de la tensión.

Palabras-clave: Trauma psíquico. Compulsión a la repetición. Habla. Metáfora. 


\section{Introdução}

A repetição é um conceito fundamental da Psicanálise. Ele foi elaborado por Freud (1969; 1976) durante a primeira metade do século XX, e Lacan (2008) o reformulou na década de 1960, dando-lhe novos contornos teóricos. $\mathrm{Na}$ atualidade, as observações da clínica permitem vários desdobramentos do tema, levando-se em consideração o sofrimento e sua possibilidade de ressignificação. O corpo, nesse contexto, apresenta-se como palco onde se manifestam efeitos do trauma e possível elaboração simbólica.

Diante da complexidade dos conceitos psicanalíticos, por um lado, e da impossibilidade de demonstração e/ou transmissão de uma práxis clínica, por outro, entendemos, a partir de Freud (1976), que a literatura e as artes em geral podem trazer grandes contribuições ao estudo psicanalítico. Para Freud, o escritor verdadeiramente criativo se antecipa à ciência, embora sem saber, na medida em que descreve a respeito do psíquico: “... a descrição da mente humana é, na realidade, seu campo mais legítimo; desde tempos imemoriáveis ele tem sido um precursor da ciência e, portanto, também da Psicologia científica" (idem, p. 50). O escritor criativo não pode ignorar o psicanalista, do mesmo modo que esse precisa levar em consideração o escritor criativo: "o tratamento poético de um tema [psíquico] pode revelar-se correto, sem qualquer sacrifício de sua beleza" (idem, p. 51).

Não pretendemos confundir o campo ficcionista com o clínico, no entanto, é notório que, na análise, trabalha-se com a narrativa do paciente, o que não deixa de ser uma versão dos fatos. Freud conhecia muito bem esse artifício da linguagem humana. Ele recebeu prêmio de literatura, de modo que sua genialidade não se reduziu, simplesmente, à descoberta científica. Vieira (2012) observa: "o próprio Freud reconhecia que seus relatos se liam como romances, e não faltaram filmes que tomaram os pacientes de Freud como seres de ficção" (p. 708).

Diante dessas considerações, pensamos que a arte do cinema pode contribuir para a reflexão no campo clínico.
Nosso objetivo é apresentar certas expressões do sofrimento, marcadas pela repetição, a partir do filme A vida secreta das palavras, articulando-as à clínica psicanalítica e às possibilidades de simbolização, tendo o corpo como instância de excesso do real. Inicialmente trataremos do conceito de repetição, segundo a teoria freudiana e as considerações teóricas de Lacan; enfocaremos o trauma e seus efeitos, testemunhados pelas marcas no corpo, e a repetição como tentativa de representar o irrepresentável. Em seguida, situaremos a clínica psicanalítica como lugar da repetição e da palavra, apontando o corpo como metáfora, e apresentaremos uma observação clínica no contexto da fala metafórica. Nossas conclusões são de que o próprio ato repetitivo porta a diferença, e que não basta esgotar a tensão do ato, gerada pelos efeitos do trauma; há que se dar vida à palavra a partir do processo de simbolização, efeito do trabalho clínico.

O filme $A$ vida secreta das palavras, de Isabel Coixet, apresenta a jovem Hanna Amiran, com pouco mais de 20 anos de idade, empregada numa fábrica de plásticos há quatro anos. Ela nunca tirou férias, não faltou ou chegou com atraso ao trabalho. Mora sozinha, não tem amigos nem se relaciona com os colegas do emprego. Telefona para sua "orientadora psicóloga" com frequência, mas não fala. Quando o gerente lhe diz que deve tirar férias, fica surpresa e pergunta preocupada: "um mês inteiro?" Em viagem de férias, a moça não sabe o que fazer. Na bolsa, conduz vários sabonetes (todos iguais: brancos e retangulares), tirados de um estoque que mantém em casa - para lavar as mãos. Também leva peças de bordar - pano, bastidor, linha e agulha -, com que tem se ocupado nas horas vagas. No ônibus em que viaja, tece, como se nada mais lhe interessasse. Utiliza-se das mesmas roupas e tipo de comida, como de costume. Num restaurante, enquanto faz refeição, ela observa um desconhecido, na mesa ao lado, que fala ao telefone: "onde vou achar uma enfermeira para cuidar dele enquanto o tiramos daí?" Em seguida, Hanna se apresenta: "Sou enfermeira". Seguem para uma plataforma de petróleo em alto-mar, onde ela passa a cuidar, voluntariamente, do homem gravemente ferido por ocasião de um incêndio. Ele tem queimaduras profundas por todo o corpo e não enxerga. Enquanto assistido, e aos poucos, 
o paciente encontra oportunidades para falar à enfermeira sobre conflitos pessoais até então não revelados. Sem se dar conta, depois de escutá-lo e resistir a falar sobre si, a moça revela um episódio da sua vida.

\section{O conceito psicanalítico de repetição}

O campo da repetição, como conceito fundamental da Psicanálise, vai do trauma à ressignificação dessa experiência, tendo o corpo como palco das implicações pulsionais. O filme A vida secreta das palavras apresenta, por um lado, os efeitos de um trauma psíquico, gerador de intenso sofrimento; por outro, a função da palavra como recurso terapêutico. Ele serve ao estudo da repetição porque é típico dos casos estudados pela Psicanálise e que aparecem na clínica.

Freud menciona o termo compulsão à repetição nos seus Estudos sobre a histeria (Freud, 1974). No pós-escrito do Caso Dora, ele observou que a paciente havia repetido na análise, abandonando-o, como o fizera com o Sr. K. (Freud, 1977). O conceito de repetição, no entanto, somente começa a ser metapsicologicamente elaborado a partir do artigo Recordar, repetir e elaborar (Freud, 1969), consolidando-se com o texto Além do princípio de prazer (Freud, 1976).

A repetição é gerada por consequência de uma situação traumática que ameaça a organização psicológica da pessoa. O trauma é produzido por um alto nível de excitação, cuja magnitude é impossível de ser dominada pelo aparelho psíquico. Esse, frente à circunstância traumática, põe em movimento todas as medidas defensivas possíveis, provocando distúrbio em grande escala e comprometendo o equilíbrio da vida psíquica (Freud, 1976). Hanna, a personagem do filme, viveu um estado de violência com efeitos impronunciáveis, cuja pulsão resvalou no corpo, e as marcas que carrega, em forma de cicatrizes, testemunham o fato. Ela encontra-se imobilizada por um sofrimento velado, movida por automatismo de repetição: uma série contínua de atos idênticos, no seu fazer diário, desprovidos de finalidade, de modo que tudo lhe parece insípido. Presa às marcas do trauma, procura, insistentemente, e sem saber, algo da ordem do sofrimento, ou da morte, no contexto da pulsão.

A pulsão de morte tende a esgotar, de vez, toda a excitação, até a condição de inércia, uma tentativa de voltar ao estado anterior à estrutura psíquica (Freud, 1976). Sua força exige descarga a qualquer custo, para isso não importando o nível de sofrimento nem seus efeitos, pois se trata de uma determinação exclusivamente pulsional, isto é, pura intensidade. A repetição expressa um viés dessa pulsão sob dois aspectos: a pulsão não descarrega nem se liga à representação, o processo se repete, indeterminadamente.

Uma vez que repetir é ato determinado pela pulsão, a pessoa se vê implicada numa espécie de coação, impulsionada a agir de certa forma, embora isso lhe cause intenso sofrimento e falta de compreensão do que seu ato possa significar. Ela repete, cotidianamente, situações de um passado remoto, nunca vinculadas ao prazer, ou age de maneira repetitiva no fazer diário. Essas formas de ação, além de se apresentarem desprovidas de sentido, ao mesmo tempo impedem a visão de possibilidades de saída do círculo repetitivo; a criatividade é seriamente comprometida. Dito de outro modo, a pessoa não consegue se desvencilhar de traços do trauma, isto é, ela continua implicada nele, numa tentativa de voltar àquele estado de sofrimento, ponto a partir do qual foi interrompido o fluxo da pulsão.

No contexto do desenvolvimento do conceito de pulsão de morte por Freud observamos que a repetição é um movimento necessário à estruturação da vida psíquica. $\mathrm{O}$ sofrimento repetido, insistente e compulsivamente, sinaliza a existência de algo que precisa ser elevado ao nível da fala e assim elaborado. É o que se pode inferir a partir das Novas conferências introdutórias sobre Psicanálise, quando Freud escreve que a compulsão à repetição surge como capacidade de regenerar; uma "pulsão de recuperação, a qual, ao lado da ajuda terapêutica, devemos nossas curas..." (Freud, 1976, p. 132). Desse modo, a repetição constitui função restauradora do psíquico.

Jacques Lacan teorizou a repetição, depois de Freud, no contexto da pulsão de morte, isto é, numa dimensão além do princípio de prazer. 
A repetição está no campo do real. Esse é um conceito lacaniano e designa aquilo que se encontra na ordem do não assimilável pelo sujeito, o que sobra do que foi simbolizado. Lacan diz que há um real no trauma, aquilo que resiste à simbolização. Ele é impensável, no entanto, impossível de ser evitado e de ser suportado e ao mesmo tempo constitui o fundamento do desejo. O real tem essa implicação na medida em que "não cessa de não se inscrever" (Lacan, 2008), porque, sendo inapreensível, ele não se inscreve e, no entanto, mantém-se, insistentemente, no "caminho" do sujeito, como algo a ser inscrito e que não pode ser. É nele que o inconsciente se sustenta.

Não se sabe onde está o real. Há, no entanto, um lugar a que ele sempre retorna, lugar do trauma e em que o sujeito não o encontra. Ele está em todos os lugares e em nenhum deles, ao mesmo tempo, porque o sujeito não o alcança, mas é por ele determinado. Observamos, desse modo, que o real sempre está em movimento mas não é visto devido à "cegueira" do sujeito: "... há um encontro marcado, ao qual somos sempre chamados, com um real que escapa" (Lacan, 2008, p. 59).

Lacan (2008) afirma que repetição é o encontro com o real e acrescenta: "encontro falho". Um encontro fadado, sempre, ao fracasso. Entendemos que isso é assim devido, por um lado, ao fato de o real ser aquilo que não aparece na sua materialidade e, por outro, à fugacidade dessa aparição. O sujeito é assombrado por algo que está ali, cujas evidências até aparecem no sonho, por exemplo, mas logo se esvaem, deixando um rastro perturbador.

O encontro falho também pode ser pensando no sentido de um desencontro, literalmente, ou pelo fato de o programado não ter correspondido à expectativa. Isso é o que comenta Soler (2004), quando faz referência à repetição. Num encontro agendado sempre há uma insatisfação, seja pelo desencontro ou pelo que se esperava dele, expectativa não correspondida, de modo que há, sempre, um déficit: "todo encontro, qualquer que seja, é deficitário com respeito à aspiração, à expectativa" (Soler, 2004, p. 100).
A repetição consiste nessa busca incessante que, por visar o impossível, não obtém êxito. A pulsão não atinge o objetivo, por isso é cada vez mais persiste em sua busca, nunca se satisfazendo. Nesse ponto, afirmamos que o não atingimento da meta não significa que haja fracasso total. Alguma coisa pode acontecer nessa recorrência insistente.

$\mathrm{Na}$ elaboração do conceito de repetição, Lacan (2008) se utiliza dos termos Tiquê e Autômaton, tomados dos estudos de Aristóteles sobre As quatro causas. Dentre elas, há uma que representa o princípio de movimento, chamada causa Eficiente e Acidental das coisas, e que se refere, exclusivamente, a acontecimentos excepcionais em meio à regularidade da natureza. "Eficiente" porque produz um resultado, "acidental" porque não tem relação com seus efeitos, de modo que não se pode prevê-los com exatidão. "Os seres e os eventos excepcionais, denominados por Aristóteles de acidentes (symbebekota), vêm a ser a partir de causas também acidentais, definidos como sorte (tyche) e acaso (automaton)" (Silva, 2009, p. 9).

Tiquê e Autômaton aparecem juntos. A Tiquê tem uma finalidade e está relacionada à escolha, por isso no âmbito, apenas, da ação humana; o Autômaton está na ordem do inesperado e da não escolha, ele é mais amplo porque se relaciona aos animais, coisas e crianças, acontece quando uma "...causa externa vem a ser não em vista daquilo que resulta" (Aristóteles, apud Silva, 2009, p. 75). Ressaltamos, ainda, que no sentido grego, da antiguidade, Tiquê está associada a uma força divina desconhecida, porém nomeada, enquanto que Autômaton seria o que "se move por si mesmo", sem qualquer determinação (Garcia-Roza, 2003).

Lacan (2008), no Seminário 11, em 1964, introduziu os dois termos no contexto da Psicanálise, onde eles adquirem sentido específico porque são pensados na ordem do inconsciente, mas sem perder o sentido etimológico. Nessa perspectiva, a Tiquê representa ordem e encontra-se, de alguma forma, com finalidade, porque nela há determinação; o Autômaton, ao contrário, está no âmbito do disperso, ou da pulsão desligada, fora de qualquer determinação. Na Tiquê, a 
força causadora do acontecimento psíquico é desconhecida para o homem, no entanto há certo grau de deliberação dele - ainda que pela via da divindade. Sem saber, o sujeito criou condições para o acontecimento, tem certa responsabilidade por ele.

O acaso, no contexto da Psicanálise, não é obra de pura dispersão, e isso corresponde ao sentido original dos termos gregos. Silva (2009), no seu artigo Sobre as causas em Aristóteles, escreve que "as causas acidentais vêm a ser apenas em relação a uma conexão causal regular anterior, elas são interferências em processos causais já existentes" (p. 78), o que nos indica que o acaso está sob algum tipo de deliberação. Isso atesta que o imprevisível encontra-se, muitas vezes, dentro de um programa, isto é, na ordem do previsível. Em Lacan (2008) há duas considerações importantes nesse sentido: ele diz que a repetição necessita do arbitrário e do acaso, que o disperso e aquilo que porta uma determinação não podem ser pensados separadamente, um independente do outro.

Nessa perspectiva, acaso e arbitrário são elementos de um mesmo conjunto, de modo que a repetição não pode ser pensada apenas como algo determinado, por um lado, ou pura dispersão, por outro. Isso se justifica quando Lacan nos diz que a Tiquê está por trás do Autômaton, isso é, enquanto esse se objetiva na medida em que o sujeito repete do mesmo modo, há, por trás disso, o "trabalho psíquico" que se constitui no encontro/desencontro como o real. Em outras palavras, trata-se do encontro marcado e da desventura dele e das consequências desse "desencontro": acontecimento imprevisível, mas fortuito, que produz novidade.

A Tiquê pode ser assim ilustrada: um vendedor foi ao mercado, certo dia, para negociar mercadorias. Aconteceu de não ter recebido o produto objeto do seu trabalho, por isso ficou em movimento, oscilante, ocupando-se em diversas atividades durante o expediente. Nesse "ir-e-vir", encontrou-se, então, com um homem que lhe devia certo valor em dinheiro, cuja dívida foi quitada. Tanto o credor quanto o devedor não saíram de casa para o devido ajuste, mas aconteceu. Dir-se-ia ser pura sorte. No sentido da Tiquê, não se trata disso, a sorte é apenas aparente. O suposto imprevisível já se encontrava no programa das relações de débito e crédito, a dívida haveria de ser paga.

A Tiquê é esse movimento que diante do impossível e por causa dele desvia-se para o inesperado, a sorte, aparente acaso. Ela é discreta, está na ordem do impossível, mas sob a possibilidade de algo diferente, algum sentido. O Autômaton se apresenta como ato e não porta sentido algum. A Tiquê está no ato falho, no lampejo, na abertura fugaz do inconsciente, porque o real se mostra - não por ele mesmo e sim por um representante possível - mas não se representa. O Autômaton é cego, mais primário, pura intensidade, volume bruto. A Tiquê é um encontro a partir do desencontro com o real que escapa, sempre; ela é marcada na análise. É nessa dinâmica, no vacilo pelo qual há aberturas do inconsciente - pela busca incessante e oportuna - que se produz o sentido, isso é, algo que acontece inesperadamente, a novidade.

A situação analítica, por meio da associação livre, põe o sujeito em estado de tensão na medida em que o faz se deparar com o inesperado. Ele diz sem saber o que está dizendo e, ao dizê-lo, surpreende-se. A surpresa se dá pelo que ocorreu acidentalmente. Por ocasião das aberturas do inconsciente, alguma coisa escapa e dá-se o acontecimento fortuito, porque algo do sujeito se apresenta a ele mesmo, estranhamente, e o conduz à mudança. Isso não é por acaso, é efeito de uma aventura própria àquele que se dá ao trabalho analítico, à perlaboração. O imprevisível, nesse contexto, tem uma razão de ser, acontece por algum movimento que vai além da consciência, mas de modo que há, sempre, um programa que o prevê. No caso da repetição, o encontro previsto não ocorreu porque o significante não encontrou outro significante, deixando o sujeito impedido à cadeia significante, isso é, instalou-se a ausência de um complemento. Enquanto se persiste nessa errância, acontece o fortuito, uma ordem de relação significante, S1-S2, estado de cadeia pelo qual o sujeito se dá conta de saberes até então desconhecidos, que o mobilizam à mudança. Isso somente é possível quando a palavra é endereçada ao outro, na análise. Na vida diária, ao contrário, os automatismos de repetição imperam, sem perspectiva de saída do círculo repetitivo. Ou seja, fora da análise valoriza-se o previsível, 
desconsiderando-se qualquer importância daquilo que se dá "como por acaso". Por isso que a razão recomenda os encontros agendados, com lugar e hora marcada, cuja formalidade significa prevenção contra o inesperado, a aventura. Nesse sentido, o compromisso se opõe ao acaso.

Automatismo de repetição consiste na insistência que vem do inconsciente e que contraria o princípio de prazer, "uma insistência particularíssima" diz Lacan (1985). A palavra automatismo, nessa perspectiva, não se encontra no contexto neurológico, "não é assim que se deve entendê-la. Trata-se de compulsão à repetição" (Lacan, 1985, p. 82). A insistência é um desprazer, um sofrimento que volta sempre, situada no além do princípio de prazer. A pulsão de vida, regida por um princípio, e a pulsão de morte, regida por outro, andam juntas, como figura-fundo; ora uma se evidencia, ora outra. Quando essa parceria se decompõe, "quando um dos componentes funciona sozinho, aparece, então, a pulsão de morte", diz Lacan (1985, p. 90).

Esse é o imperativo do Autômaton. Ele é pulsional mas não propriamente a pulsão. Enquanto essa pressiona continuamente, o Autômaton é movido por uma descontinuidade, estagnação pulsional que abruptamente se apresenta de qualquer jeito, "algo que atua às cegas, sem intenção... age 'como se', como se houvesse uma finalidade, mas não há" (Soler, 2004, p. 31). O Autômaton está na ordem do significante puro, fora da cadeia, cujo sujeito por ele é possuído, isso é, o significante governa os objetos do desejo, e o sujeito é possuído pelo objeto. Soler cria uma fala com o objetivo de explicar o poder do significante puro na repetição. O significante diz ao sujeito:

sou eu quem faz com que os objetos dos seus desejos se multipliquem e se fortaleçam... crês atuar quando eu te agito ao capricho dos laços com que anulo seus desejos. Assim, estes cobram força e se multiplicam em objetos que lhe devolvem a fragmentação da sua infância desgarrada (Soler, 2004, p. 63).

A ideia é de que o sujeito recebe significante e pode se alienar a ele, isso ocorre pela impossibilidade da cadeia significante.
A impossibilidade de inscrição do que não tem representação, e sua respectiva insuportabilidade, produz automatismos de repetição. O sujeito cai na mesma vala, res-vala, re-cai, re-incide, repete, ou seja, tropeça, cai no mesmo lugar automaticamente, sem mirar a diferença ou algum sentido, preso à mesmíssima coisa, impelido pela pulsionalidade habitual, sobre o mesmo trilho, às cegas, sem finalidade. Produz-se uma série contínua de atos repetitivos, sem ruptura. Por outro lado, em meio a essa profusão de acontecimentos, dá-se um encontro, uma espécie de encaixe, algo da ordem do simbólico. É quando se estabelece uma ruptura da continuidade repetitiva, que dá lugar à criatividade.

Hanna, no filme, busca a ordem do impossível, a situação do trauma, o real. Sua recorrência ao sofrimento indica a possibilidade de voltar ao lugar do entrave, única chance de desfazê-lo, por isso identifica-se com a figura de um corpo dilacerado, o do paciente. Ela "teve sorte", no sentido da Tiquê: o outro, também marcado no corpo, revela parte de sua vivência emocional, e ela se permite contar, também, a respeito do que a atormenta, até então fora do alcance da palavra. É guiada, na sua fala, pelas marcas impressas no próprio corpo, cujo ouvinte, cego, as identifica pelo tato: dá-se o "corpo a corpo", corpos marcados e portadores de sofrimento, inconsciente para inconsciente.

Ao fazer uso do sabonete, do qual não se distanciava, Hanna insistia em repetir, retomar/ revisitar as "marcas do trauma" - testemunhadas no corpo - , apesar do sofrimento, numa tentativa desesperada para apagá-las, forma de depurar, dissipar o que repugnava.

Os atos de Hanna se constituem repetição na medida em que tentam inscrever o impossível de ser dito no campo da palavra. Não se trata de simples recordação, nela predomina o além do princípio de prazer. Lacan (2008) distingue repetir de recordar. A recordação esbarra no limite do real, de modo que não o atinge. Na repetição, por outro lado, o sujeito insiste sempre, movido pela aproximação, ainda que essa seja enganosa, e não obtém êxito devido à fugacidade da aparição do real; no entanto, devido à persistência do desejo, dá-se o furo no real. A recordação aguça o sofrimento e 
não apresenta perspectiva de mudança, ela não leva a nada, enquanto que a repetição produz efeitos de articulação simbólica, uma vez que se dê no contexto analítico.

\section{A clínica psicanalítica: lugar da repetição e da palavra}

É na clínica, através da palavra, que a repetição pode romper seu caráter serial, fazendo circular a pulsão. Na análise, produz-se a tensão do encontro/desencontro com a experiência do trauma, e isso mobiliza o sujeito, capacitando-o à produção de algum sentido.

Ressaltamos, nesse contexto, a disposição interna do analista. Ele se põe no lugar do impossível e, sobretudo, do possível, isso é, lugar do objeto a e lugar do outro simbólico. $\mathrm{Na}$ medida em que o sujeito se endereça ao outro (semelhante), também o faz, sem saber, a esse outro do inconsciente. Pondo-se no lugar do outro, o analista funciona como suporte para o trabalho psíquico. Sua fala suscita palavras, no analisante, que podem trazer à tona experiências afetivas indizíveis. Desse modo, o inconsciente de um e do outro produzem aberturas pelas quais a análise avança.

Freud (1976, p. 34) observou que é no campo transferencial que a repetição se expande, apresentando-se ao trabalho psíquico: "os pacientes repetem na transferência ... situações indesejadas e emoções penosas, revivendo-as com a maior engenhosidade". No espaço analítico, a pessoa vive o sofrimento de antigos conflitos como algo do presente, ignorando qualquer vínculo deles com o passado. A tensão gerada como algo do presente deve-se à presença do analista, cabendo a ele saber como recepcionar o que the foi endereçado. Nesse ponto, diz Freud (1976, p. 531), “... retemos a totalidade da libido que foi retirada do domínio do ego, atraindo uma parte dela sobre nós próprios, mediante a transferência".

A libido endereçada ao analista é aquela concentrada no sintoma e que foi subtraída do ego. É preciso liberar essa libido, pondo-a, novamente, à disposição do ego (Freud, 1976). Assim, o sintoma se torna aliado do tratamento, dando-se ao trabalho psíquico. Dito de outro modo, o analista deve se tornar acessível às novas edições dos antigos conflitos, ao que o analisante reedita e endereça a ele; é nessa medida que o sintoma se torno analítico, porque reconstitui o conflito. É somente pela palavra que essa operação se torna possível, e seu analisante, em algum momento, há de tomá-la no sentido de se posicionar.

Freud foi um homem de palavra desde o princípio da sua trajetória clínica. Quando sua paciente Emmy Von queixou-se a respeito de como lhe eram feitas as perguntas e reivindicou falar a seu modo, ele a acatou: "concordei com isso, e ela prosseguiu sem mais preâmbulos" (Freud, 1974, p. 107). Essa palavra é o dito espontâneo, efeito da associação livre. De palavra em palavra, o sujeito roça a obscuridade do indizível e ao invés de a energia psíquica se descarregar livremente, o circuito da repetição é alterado, possibilitando a simbolização da experiência traumática.

No tratamento, a fala se permite, tendo como coadjuvante o corpo. Esse, como instância pulsional por excelência, guarda segredos, porque é inconsciente e mantém o recalcado. A descarga emocional, por si só, não basta. É preciso ser reavaliado o que foi recusado pela consciência, trazendo-se a experiência do trauma à palavra. Por isso a recordação não produz efeito simbólico, ela gera, apenas, tensão e descarga. Somente a palavra é capaz de fazer alterar-se a experiência do trauma e produzir sentido. Desde o início de suas pesquisas no campo clínico, Freud se deu conta de que a função da palavra vai além da ab-reação; uma vez na transferência, ela adquire consistência enquanto mecanismo no sentido da perlaboração, isso é, o trabalho psíquico.

Uma vez que a repetição ocorre diante daquilo que nunca pode ser recordado, a palavra é instrumento de embate frente ao impossível. Ela martela, vacila na tentativa de reencontrar $o$ " $x$ " da questão, indeterminadamente. Nesse desencontro com o real - campo do impossível -, a palavra presta sua função de encontro com o sentido, articulando significantes, de modo que se produz uma espécie de "encaixe", porque as coisas se vinculam, apesar de 
sempre restar algo que resiste a esse processo simbólico. Por trás de cada ato repetido - o "martelar" - há um novo saber que surge, e ao invés de uma desestruturação que ponha em risco a vida psíquica, cria-se o espaço da possibilidade, dando-se um novo contorno àquilo que se havia constituído como trauma.

No filme, a fala de Hanna, até então aprisionada, desabrocha, jorra contornando o real que não cessa de não se inscrever. Na medida em que é escutada, ela consegue revelar parte de um acontecimento: havia sido violentada brutalmente, dilacerada no corpo e na alma, enquanto presenciava o sofrimento de outras pessoas que morriam em consequência de torturas, de modo que essas a atingiam, direta e indiretamente. É seu corpo quem se adianta e conta a história, porque as palavras ainda não alcançam, elas apenas tentam dizer, ensaiam precariamente articular nome para aquilo que é indizível, num esforço sem fim que, no entanto, não é em vão.

Havia uma amiga - diz Hanna com grandes dificuldades - com quem estudava e se dava muito bem. Depois da guerra, ambas deixaram a universidade e decidiram voltar para sua cidade, um pouco distante. Por toda a viagem, viram estragos da guerra. Soldados pararam o carro que as conduzia e levaram-nas para um hotel, juntando-as a outras pessoas em idênticas condições. A princípio, pensaram que iam ser roubadas, depois viram que seriam protegidas, pois os soldados eram tropas da ONU, jovens que falavam a mesma língua (delas). No entanto, eles abusaram, torturando-as. Sofrida e pausadamente, com intervalos, Hanna conta a seu paciente:

Imagine que eles nos estupravam várias vezes e sussurravam nos nossos ouvidos, para que só nós ouvíssemos: "Desculpe. Sinto muito. Perdoe-me". Éramos 15 mulheres, às vezes mais, mas nós sabíamos que, quando a comida acabasse, eles matariam algumas de nós. Fizeram uma mulher matar a filha. Colocaram uma arma na mão dela, colocaram o dedo dela no gatilho, puseram o cano da arma na vagina da menina e eles a fizeram apertar o gatilho, dizendo algo como: "Agora você não vai ser avó", algo assim. A mulher morreu logo depois, de sofrimento. Um dia amanheceu e ela tinha morrido de sofrimento. Sabe o que eles fizeram com as que ousaram gritar?
Eles disseram: "Agora vamos dar motivo para vocês gritarem". E faziam centenas de cortes nos corpos delas, com uma faca, esfregavam sal nas feridas e costuravam os cortes mais fundos com agulhas. Foi o que fizeram com a minha amiga. E eu não pude... não me deixaram limpar as feridas dela. Então ela sangrou lentamente até morrer. Foi tão... foi tão lento. O sangue escorria dos braços e das pernas dela. Eu rezava para que ela morresse logo. Eu contava os gritos. Os gemidos. Eu media... a dor. E eu pensei: "Ela não pode sofrer mais. Agora ela vai morrer. Agora. Por favor. No próximo minuto. Por favor" (fala de Hanna, personagem de A vida secreta das palavras).

Tendo proferido essas palavras, insuficientes para relatar a experiência traumática, Hanna toma a mão do enfermo, pondo-a sobre suas cicatrizes, ao redor dos seios, e ele as lê através do relevo, das marcas imprimidas no corpo da moça. Afetado pelos sinais da crueldade, ele quis saber o nome da amiga de Hanna. Perguntou por várias vezes, tendo como resposta o silêncio. "Qual era o nome da sua amiga?", indaga mais uma vez. Ela, relutante, enfim diz: "Hanna".

No dilema entre a insuportabilidade da dor e o não saber dizê-la, o sujeito põe em questão a relação eu-outro. $\mathrm{O}$ eu, como interno, confunde-se com o outro, externo. Não se distingue o dentro do fora, tal a superfície de möebius na qual o interno e o externo se encontram na mesma dimensão, isso é, o dentro e o fora não são distintos nem se opõem. Freud (1976) observou que no aparelho psíquico há um escudo protetor que filtra os estímulos externos, impedindo a entrada de intensidades cuja magnitude o aparelho não suporta. Desse modo, a pessoa pode se livrar daquilo que é externo - ressaltamos que Hanna era surda, utilizava aparelho reparador de audição: "ouço quando quero", havia ela dito ao seu paciente. No caso de estímulos internos, porém, não há como se defender, de modo que o eu cria um artifício para lidar com essas situações, então ele projeta no outro aquilo que se encontra em si. Isso é, o que é interior projeta-se para fora, e assim pode ser evitado, ser suportado ou dominado, de alguma forma, porque o aparelho se mobiliza para assimilá-lo. Hanna não consegue ver no seu interior o absurdo que a atormenta, ela o enxerga no exterior, uma tentativa desesperada 
de lidar com o sofrimento. Apesar do esforço, das palavras que aproximam Hanna da realidade psíquica traumatizante, ela ainda não fala em seu próprio nome, o eu não suporta tamanho mal-estar, ele se confunde com o outro.

Muitas vezes, é a partir do exterior que é possível relatar o que se encontra no interior. Desse modo, o corpo funciona como palco do esforço para nomear a experiência afetiva do trauma, fazendo com que a pulsão possa ser representada. Hanna vê a si própria num outro corpo, o do paciente - literalmente dilacerado -, o que suscita, nela, palavras. Nem assim sua fala pode dizê-lo. Então ela "enxerga" a amiga (o externo) e nela "identifica" o seu próprio sofrimento (interior). Finalmente, à custa de muito esforço, no último momento, é possível, pelo menos, fazer aparecer parte do indizível, diante da escuta: "qual era mesmo o nome da sua amiga?"

Isso corresponde à fala de Lacan (2002), no Seminário 22, a propósito da ex-sistência. A área entrelaçada do nó Borromeano é o campo da existência, ela "ex-siste" às consistências do real, do simbólico e do imaginário. O ex é o que faz contorno, um fora que, ao mesmo tempo, não deixa de ser dentro, porque dá consistência a esse último, de modo que um não se sustenta sem o outro. No caso de Hanna, o imaginário sobrepõe-se ao real para, só assim, viabilizar o simbólico. Dito de outro modo, ao apontar o outro, imaginariamente, como objeto-imagem de si mesmo, Hanna nos faz observar esse objeto como "ex-sistência", um fora que dá consistência ao que está dentro. Esse caminho conduz ao real, causando, nesse, um furo pelo qual algum fragmento dele pode ser representado, levando Hanna, finalmente, à fala sobre sua dor. O simbólico, nesse momento, sobrepõe-se ao imaginário.

Na clínica, o sujeito se depara com o real; a palavra traz à tona aquilo que não tem representação e põe a possibilidade de uma reconsideração do recalcado. Sendo o corpo uma instância psíquica, ele funciona como metáfora, é fora e dentro ao mesmo tempo; a metáfora dá consistência ao interno/externo. A fala analítica é capaz de fazer o imaginário sobrepor-se, até certo ponto, ao real, causando o furo. Para isso, a palavra do analista precisa se fazer metafórica, em relação com a do analisante.

A metáfora consiste em transportar uma palavra de um contexto a outro, conservando a mesma ideia. Ela é utilizada quando não se sabe o nome preciso para determinada coisa e se diz um nome no lugar de outro, embora, no caso da clínica, o sujeito não se dê conta. Isso é quando a pessoa não dispõe de palavra para nomear a experiência traumática, ela diz uma coisa com o nome de outra. Implica um deslizamento da literalidade da palavra. A palavra metafórica, nesse contexto, torna-se instrumento de linguagem capaz de promover uma aproximação do indizível, ela se faz terapêutica na medida em que não explica a coisa diretamente; ela suscita palavras, em cadeia, capaz de nomear o que não pode ser dito.

Freud observou esse fenômeno em diversos momentos da sua teoria. Ele constatou que "as intensidades das ideias individuais tornam-se capazes de descarga en bloc e passam de uma ideia para outra, de maneira que formam certas ideias dotadas de uma grande intensidade" (Freud, 1972, p. 633). Muitas vezes, as palavras passam por uma condensação, cujo deslocamento transfere investimentos de umas para outras: "o processo pode ir tão longe que uma única palavra, se for especialmente adequada devido a suas numerosas conexões, assume a representação de todo um encadeamento de pensamento" (Freud, 1972, p. 227).

O corpo, como uma palavra, condensa. Suas marcas portam, muitas vezes, grandes intensidades não representadas. Por outro lado, a fala do analista produz efeito de sentido, ou seja, ela pode fazer aparecer, no sujeito, algum conteúdo que se encontra no nível dessa condensação, articulando-se à palavra, podendo ser nomeado. Nesse sentido, há situações pelas quais analista e analisante são marcados pela metáfora: um deles propõe a metade de uma "peça", esperando que o outro disponibilize a outra metade, de modo que se forme um único tecido. Hanna, diante do corpo do outro, marcado por queimaduras e pela cegueira, volta-se para si mesma, esforça-se no sentido de "tecer" nova unidade do seu corpo, despedaçado pelas circunstâncias do 
trauma. Ela já vinha fazendo isso nas suas repetições diárias, nos interstícios das ocupações, sem saber - no "tempo vago". Ao tecer seu bordado, Hanna esforça-se para dar relevo à experiência subjetiva sem representação, tal as cicatrizes no seu corpo. Ela tenta contornar, pelo bastidor (circunferência de madeira que estica a superfície do pano, onde deve ser efetuado o bordado), aquilo que ainda não tem forma, porque se encontra oculto, disperso. Insiste em delimitar a superfície vazia, fazer "bordas" naquilo que ainda não porta um sentido. Único meio possível de tecer sua dor.

Sob os efeitos da linguagem - vulnerável ao mal-entendido -, no entanto, o simbólico nunca é tecido na suja totalidade, as partes se encaixam perfeitamente, no sentido da unidade. Porém, o trabalho psíquico não é em vão. Através da palavra é possível, sempre, alguma via pela qual surge a novidade, dando sentido à parte estilhaçada da pessoa, ao que foi perdido por força do recalque. Então, o que era impossível de ser dito é considerado, trazido para o campo da linguagem, podendo ser nomeado. É o que demonstra a seguinte observação clínica:

Uma paciente da nossa clínica achava-se incapaz de associar livremente e sofria. Certo dia, ela disse: "hoje não vim para falar, estou oca". Na mesma sessão, comentou sobre um documentário de TV visto por ela nos últimos dias. Um homem penetrava num daqueles buracos onde se escondiam os vietnamitas em guerra: "uma vala subterrânea, estreita, muito estreita, sem luz, sem ar. Eu não consigo, sequer, pensar naquilo. Isto me sufoca, é apavorante" (negrito nosso).

Pensei o "oco" como ausência de forma, vazio sem tonalidade, sem miolo. A paciente se recusava a olhar, sentir ou ver esse "abismo" em si mesma. Ela transportou o sentido da realidade externa ("buraco") para a interna, sem saber. Certamente havia um "buraco" psíquico, um vazio de sentido. A metáfora sugeria, ainda, a ideia de uma guerra, cujo inimigo mortal the era desconhecido, do qual se resguardava. Ela não suportava ver esse inimigo dentro de si - afeto sem representação, o vazio -, o buraco. Chamou-me a atenção o termo "aquilo" aludindo ao buraco, seguindo-se de "isso", em referência a ela mesma: "isso me sufoca, é apavorante". Aquilo, enquanto realidade objetiva, distante dela, foi utilizado como recurso para nomear o isso, realidade íntima, ainda sem nome, e que precisava ser significada.

Então eu disse: "Você deve estar se referindo a alguma coisa dentro de você, algo insuportável". Em outra sessão, a paciente relatou uma experiência de infância, nunca mencionada. O tratamento avançou significativamente, a partir daquela "nomeação metafórica", tendo a paciente se tornado capaz de trazer à tona uma experiência até então impossível ao campo da palavra.

O filme $A$ vida secreta das palavras termina com Hanna voltando ao trabalho, depois de cumprida a missão de tratar do homem que havia se queimado. Ela não é mais a mesma, sua rotina foi alterada, o círculo repetitivo diário sofreu ruptura, visualizaram-se perspectivas em relação ao futuro. $\mathrm{O}$ automatismo de repetição perdeu seu caráter serial. Hanna passou a não mais acomodar seu alimento em compartimentos distintos do recipiente no qual levava seu almoço para o trabalho, os diferentes ingredientes ganharam unidade. Sua vida mudou consideravelmente na medida em que a palavra foi capaz de romper o silêncio das marcas no corpo e o que se encontrava, até então, velado pelas cicatrizes traduziu-se em algum dizer. Atos criativos se destacaram na sua vida, tendo-se rompida a série evocativa do passado.

A cena final da história tem como fundo a imagem do início: a carcaça de um navio e, ao lado, seus destroços (é o que parece). Encontram-se à beira do caminho que leva Hanna à fábrica de plásticos, onde trabalha. Nessa cena, Hanna se encontra com Josef, seu ex-paciente, agora completamente recuperado, inclusive da visão, e que a procurou. O navio, no fundo, está, em parte, despedaçado, mas em terra firme, livre da corrosão inevitável e iminência de destruição. Entende-se que, antes, no curso das águas, era açoitado pela rebeldia das ondas indomáveis, disperso na solidão dos oceanos. Seus restos agora parecem disponíveis à transformação em novos objetos para serem utilizados. Assim também os personagens que ali se encontram: Hanna está fragilizada, porém aberta a novas perspectivas. 
Não mais se ocupa, com esmero, à limpeza das mãos; voltara da viagem de férias sem a mochila e os sabonetes com os quais tentava limpar o absurdo do corpo, o repugnável e asqueroso. Ela já não é solavancada por afetos sem representação nem está à deriva. Seu corpo, tecido pela palavra, parece em vias de integração, já lhe é possível um projeto de vida. Segundo o que deixa transparecer o filme, ela planeja e realiza a ideia de uma família.

\section{Considerações finais}

Toda repetição é ato impensado, mas traz, em si, a possibilidade de ressignificação da experiência afetiva do trauma. Quando o sujeito procura a análise com uma queixa, ele está se endereçando - pela palavra - a um lugar possível de produzir sentido e, ao mesmo tempo, deparando-se com o impossível de ser apreendido. Durante algum tempo da análise, nesse embate com o real, ele reclama de nada ter-lhe acontecido em termos de cura, no entanto se pega observando algumas alterações no seu modo de viver: "coisas muito simples, periféricas", disse um paciente. Esse é o tempo do trabalho psíquico.

Se no próprio ato repetitivo há ferramentas em função do trabalho de simbolização, cabe ao analista identificar certos movimentos no cotidiano do analisante - muitas vezes metaforicamente - que se fazem no sentido do trabalho psíquico. É o caso do tecer, pela personagem Hanna. A análise deve intervir nesse ponto, como apoio. Quando o passado se faz presente como intensidade (ato), ele ocupa o espaço da vida e da criatividade. É preciso um "esgotamento" dessa intensidade e, a partir disso, a transformação da experiência afetiva do trauma, a ponto de se instalar um estado de falta, ou vazio, pelo qual o desejo opera em função do novo. O filme $A$ vida secreta das palavras sugere esse processo, no qual não basta descarregar a tensão gerada pelo trauma, é necessário o trabalho psíquico, como havia pensado Freud. O repetir de Hanna não se reduz ao uso do sabonete, o expurgamento do absurdo não era suficiente, ela tinha que "tecer", dar nova configuração a si, e o fez por meio da palavra. Uma vez que essa palavra se dá na transferência, ela rompe o silêncio do corpo. Através da fala analítica, pode-se nomear o que não tem representação, dando vida à palavra.

Dar vida à palavra é libertá-la das amarras, fazê-la brotar, surgir dos escombros do trauma, das profundezas do indizível. A palavra irrompe do que está contido e condenado à segregação (afeto separado da sua representação), ela se faz representante do objeto, sai do corpo, da lágrima, do desespero, do caos. Dar vida à palavra é, sobretudo, inscrevê-la como representação - ou inscrever o que não tem nome na palavra -, pela qual o objeto é ressignificado a partir de um novo acontecimento. A palavra adquire vida quando ocupa o lugar do vazio. 


\section{Esperidião Barbosa Neto}

Psicólogo com atuação clínica. Especialista em Filosofia Política, Psicologia Social e Psicopedagogia. Mestre em Psicologia Clínica. Doutorando em Psicologia Clínica, linha de pesquisa Psicopatologia e Psicanálise, pela Universidade Católica de Pernambuco. Professor da Universidade Federal de Alagoas, Maceió - AL. Brasil.

E-mail: esperidiao.bn@ig.com.br

\section{Zeferino Rocha}

Doutor em Psicologia pela Universidade de Paris X. Membro fundador do Círculo Psicanalítico de Pernambuco. Professor da linha de Pesquisa em Psicopatologia

Fundamental e Psicanálise do Programa de Pós-graduação em Psicologia Clinica da Universidade Católica de Pernambuco, Recife - PE. Brasil.

E-mail: zephyrinus@globo.com

Endereço para envio de correspondência:

Universidade Federal de Alagoas, Instituto de Ciências Humanas, Comunicação e Artes (ICHCA). Cidade Universitária Tabuleiro dos Martins. CEP 57072-000 - Maceió, AL - Brasil.

Recebido 24/12/2013, Aprovado 05/12/2014. 
Freud, S. (1969). Recordar, repetir e elaborar. In S. Freud, Edição Standard Brasileira das Obras Psicológicas Completas de Sigmund Freud (J. Strachey, trad., Vol. 12, pp. 191-203). Rio de Janeiro: Imago. (Trabalho original publicado em 1914).

Freud, S. (1972). A interpretação de sonhos. In S. Freud, Edição Standard Brasileira das Obras Psicológicas Completas de Sigmund Freud (J. Strachey, trad., Vol. 4 e 5). Rio de Janeiro: Imago. (Trabalho original publicado em 1900).

Freud, S. (1974). Estudos sobre a histeria. In S. Freud, Edição Standard Brasileira das Obras Psicológicas Completas de Sigmund Freud (J. Strachey, trad., Vol. 2). Rio de Janeiro: Imago. (Trabalho original publicado em 1893).

Freud, S. (1976). Além do princípio de prazer. In S. Freud, Edição Standard Brasileira das Obras Psicológicas Completas de Sigmund Freud (J. Strachey, trad., Vol. 18, pp. 13-85). Rio de Janeiro: Imago. (Trabalho original publicado em 1920).

Freud, S. (1976). Conferências introdutórias sobre psicanálise. In S. Freud, Edição Standard Brasileira das Obras Psicológicas Completas de Sigmund Freud (J. Strachey, trad., Vol. 16, pp. 523-539). Rio de Janeiro: Imago. (Trabalho original publicado em 1917).

Freud, S.(1976). Delírios e sonhos na Gradiva de Jensen. In S. Freud, Edição Standard Brasileira das Obras Psicológicas Completas de Sigmund Freud (J. Strachey, trad., Vol. 9, pp. 13-98). Rio de Janeiro: Imago. (Trabalho original publicado em 1907).
Freud, S. (1976). Novas Conferências introdutórias sobre psicanálise. In S. Freud, Edição Standard Brasileira das Obras Psicológicas Completas de Sigmund Freud (J. Strachey, trad., Vol. 22, pp. 103-138). Rio de Janeiro: Imago. (Trabalho original publicado em 1932).

Freud, S. (1977). Fragmentos da análise de um caso de histeria. In S. Freud, Edição Standard Brasileira das Obras Psicológicas Completas de Sigmund Freud (J. Strachey, trad., Vol. 7, pp. 1-119). Rio de Janeiro: Imago. (Trabalho original publicado em 1905).

Garcia-Roza, L. (2003). Acaso e repetição em psicanálise. Rio de Janeiro: Jorze Zahar.

Lacan, J. (1985). O seminário: Livro 2. O eu na teoria de Freud e na técnica da psicanálise. Rio de Janeiro: Jorge Zahar.

Lacan, J. (2002). R.S.I. Séminaire 1974-1975. Paris: Éditions de l'Association Freudienne Internationale.

Lacan, J. (2008). O seminário: livro 11. Os quatro conceitos fundamentais da psicanálise. Rio de Janeiro: Jorge Zahar.

Silva, L. R. (2009). Sobre as causas em Aristóteles. Intuitio, 2(1), 67-80.

Soler, C. (2004). La repetición em la experiência analítica. Buenos Aires: Manantial.

Vieira, M. A. (2012). O homem dos lobos: a atualidade dos casos clínicos freudianos. Psicologia, Ciência e Profissão, 32(3), 706-715. 